\title{
KARDYNALAT BISKUPA KRAKOWSKIEGO JANA PUZYNY
}

Józefińskie rządy austriackie odnosiły się bardzo niechętnie do wszelkich honorowych godności, którymi Rzym papieski obdarzał księży, względnie biskupów w Cesarstwie Austriackim. Niechętnie też odnoszono się do powoływania prałatów z krajów austriackich na rzymskie urzędy kościelne. Stwierdził to książę K. L. W. Metternich w poufnej nocie z 25 III 1840 r. do hr. Lützowa, austriackiego posła przy Stolicy Apostolskiej $^{1}$. Toteż od czasu wstąpienia na tron ces. Józefa II (1780) aż do śmierci ces. Franciszka I (1835) na łączną liczbę 196 promocji kardynalskich kraje austriackie otrzymały ich łącznie z Węgrami 5 (Ołomuniec abp A. T. Colloredo prom. 17 I 1803; abp M. T. Trautmannsdorf prom. 23 IX 1816; R. J. J. arcyks. Habsburg prom. 4 VI 1819; Wiedeń — abp F. X. Salm-Reifferscheidt prom. 23 IX 1816; Ostrzyhom - abp A. Rudnay prom. 2 X 1826), podczas gdy Francja miała ich 17, a Hiszpania $10^{2}$.

Tę szkodliwą sytuację dla Cesarstwa Austriackiego uświadomiono sobie dopiero $w$ pierwszych latach panowania ces. Ferdynanda I (18351848), kiedy pap. Grzegorz XVI w nadzwyczajnych okolicznościach dokonal promocji kardynalskiej 33-letniego abpa salzburskiego F. J. F. C. Schwarzenberga (24 I 1842) ${ }^{3}$. Przekonało to księcia Metternicha, jak wielką wagę przywiązywał papież i kolegium kardynalskie do faktu, że przedstawiciel episkopatu austriackiego znalazł się po długich latach nieobecności w Rzymie. Książę wyraził przy tej okazji życzenie, by cesarz austriacki skorzystał ze swoich uprawnień i wysunął wniosek mianowania kardynałów koronnych (29 I 1842) ${ }^{4}$. W tej sprawie wystąpił w dniu 6 III 1842 r. książę Metternich i opracował specjalny memoriał, który następnie przedyskutowano wśród członków rady państwa. Tak J. A. Jüstel, członek rady dworu i państwa, zauważył, że „sprawa nominacji kardynałów koronnych należy do praw, którym najwięcej należy

1 F. Ma ass, Der Josephinismus. Quellen zu seiner Geschichte in Osterreich 1760-1850, Bd. 5, Wien 1961, nr 72a s. 569-570.

${ }^{2}$ R. Ritzler, P. Sefrin, Hierarchia catholica medii et recentioris aevi, vol. 6 (1750-1799), Patavii 1958, s. 33-38; Vol. 7 (1800-1846), Patavii 1968, s. 6-28 (cytuję dalej: Hierarchia cath.).

3 Tamże, vol. 7 s. 330.

4 F. $\mathrm{M}$ a a s s, jw., Bd. $5 \mathrm{nr} 86$ s. $644-646$, nr 93 s. 667. 
poświęcić uwagi, jako że najwyższy zarząd Kościoła na skutek zmniejszenia się liczby prałatów austriackich w kolegium kardynalskim oddalił się wielce od interesów światowych Cesarstwa Austriackiego". Przy końcu swych uwag radca Jüstel opowiedział się za wnioskiem księcia Metternicha, że w kolegium kardynalskim winni się znaleźć nade wszystko książę prymas Węgier i książę arcybiskup ołomuniecki. Tym pierwszym był wówczas od 1839 r. abp Józef Kopácsy, drugim natomiast - abp M. J. W. Sommerau-Beeckh (od 1837).

Radca Jüstel postawił też wniosek, że „,należy sobie życzyć, by cesarz, któremu przysługują odpowiednie prerogatywy, zamianował kardynałów koronnych". Powoływał się w tym względzie na Francję, która skrzętnie wykorzystywała swoje prerogatywy. Zauważył też, że austriacki kardynał koronny C. C. Gaysruck (prom. 21 V 1829) odegrał poważną rolę w czasie dwóch ostatnich konklawe. W podobnym duchu wypowiedział się również minister Franz hr. Kollowrat; zaproponował on, by wśród koronnych kardynałów znalazł się również arcybiskup Wiednia ${ }^{5}$.

A jaki wniosek praktyczny wyciągnęła rada państwa $z$ tej dyskusji? Otóż na jej wniosek ces. Ferdynand I najwyższym postanowieniem (po 24 III 1842) wyznaczył na kardynałów koronnych księcia prymasa Węgier J. Kopácsy, księcia arcybiskupa ołomunieckiego Sommerau i księcia arcybiskupa wiedeńskiego W. E. Mildego. Te też osoby zostały zalecone przez władze austriackie pap. Grzegorzowi XVI do promocji kardynalskiej $^{6}$. Z kandydatów tych tylko arcybiskup ołomuniecki doczekał się purpury, ale tę przekazał mu dopiero 30 IX 1850 r. pap. Pius IX. Wprawdzie pap. Grzegorz XVI mianował w latach 1843-1846 jeszcze 19 kardynałów, lecz wszyscy - z wyjątkiem 2 Portugalczyków - byli Włochami ${ }^{7}$. Na przeszkodzie promocji prałatów austriackich stanęły przyczyny prawodawstwa austriackiego w zakresie spraw kościelnych, a także doktrynalna postawa niektórych kandydatów do tej godności ${ }^{8}$. I tak pod adresem księcia metropolity wiedeńskiego Wincentego Edwarda Milde wysunęła Stolica Apostolska zastrzeżenia co do jego postawy ortodoksyjnej, a nawet żądała rezygnacji $\mathrm{z}$ arcybiskupstwa wiedeńskiego ${ }^{9}$.

Władze wiedeńskie nie poniechały jednak zamiarów wzmocnienia wpływów swoich w Kurii papieskiej. Miano to uczynić w 1855 r. z okazji zawarcia konkordatu ze Stolicą Apostolską. Konkordat ten głosił, że „,religia katolicka, apostolska, rzymska w całym Cesarstwie Austriackim

5 Tamże, $\mathrm{nr} 89$ s. $655-661$; Hierarchia cath. vol. 7 s. 353 (Ostrzyhom), 291 (Olomuniec).

6 F. M a a s, jw., Bd. $5 \mathrm{nr} 89$ s. $669 \mathrm{nn}$.

7 Hierarchia cath. vol. 7 s. $291,33-35$.

8 F. M a a s, jw., Bd. 5 s. 129 (przyp. 32).

9 Tamże s. 129 n., $149 \mathrm{nn}$. 
i w każdej jego części korzystać będzie z tych wszystkich praw i przywilejów, które ma z prawa Bożego i postanowień kanonicznych" 10. Przy okazji zawarcia tego konkordatu hr. L. Colloredo-Mels postanowił wzmocnić wpływy austriackie w Rzymie, a temu miały służyć:

a) obsada ambasady austriackiej przy Stolicy Apostolskiej osobą młodszą i bardziej energiczną,

b) pomnożenie liczby kardynałów koronnych w Kolegium św.

Pierwszy postulat zrealizowano stosunkowo szybko. Dnia 26 VIII 1859 r. Austria odwołała ze stanowiska ambasadora przy Stolicy Apostolskiej podeszłego w latach i chorowitego hr. Maurycego Esterházy'ego, a jego miejsce zajął hr. Aleksander Bach, dotychczasowy zastępca ministra spraw wewnętrznych, obeznany świetnie ze sprawami kościelnymi ${ }^{11}$. Sprawa zwiększenia liczby kardynałów austriackich w Kolegium św. nie stanowiła też trudniejszego problemu. Na skutek rozpoczęcia pertraktacji o konkordat między Austrią i Stolicą Swiętą, zwłaszcza po jego zawarciu, pap. Pius IX $\mathrm{w}$ alokucji Quisque vestrum z dnia 15 XII 1855 r. dał wyraz temu, że do kolegium kardynalskiego ,dokooptuje mężów, którzy będą mile widziani tak jemu samemu, jak też i cesarzowi" ${ }^{12}$.

Toteż już 30 IX 1850 r. mianował kardynałem wskazanego przez Wiedeń księcia arcybiskupa ołomunieckiego M. J. G. Sommeraua († 1853), a następnie w dniu 7 III 1853 r. prymasa Węgier Jana Scitowskiego († 1866), zaś 18 XII 1855 r. księcia arcybiskupa wiedeńskiego J. O. Rauschera ( $\dagger$ 1875). Po ratyfikacji konkordatu z 1855 r. Austria otrzymała w Kolegium św. 4 stałe miejsca. Już 16 VI 1856 r. pap. Pius IX ozdobił purpurą kardynalską unickiego metropolitę we Lwowie Michała Lewickiego ( $†$ 1858) oraz metropolitę zagrzebskiego Jerzego Haulika Váralya $(\dagger 1869)^{13}$. Odtąd ustaliła się praktyka, że kardynałów koronnych prezentował zawsze cesarz drogą poufną poprzez kancelarię państwa, ministerstwo spraw zagranicznych i ambasadę austriacką przy Watykanie.

Po 1873 r. wzmogły się naciski Austrii na Rzym, by uzyskać stałego przedstawiciela kleru austriackiego w Kurii papieskiej w Rzymie, ale liczba czterech kardynałów koronnych utrzymała się nadal w czasie pontyfikatu pap. Piusa IX ( $†$ 1878). W ciągu pięciu lat następnych (18731878) pap. Pius IX kreował aż pięciu nowych kardynałów austriackich (1873 - abp salzburski M. J. Tarnoczy i abp J. Simor, prymas Węgier; 1876 - jezuita J. Ch. Franzelin; 1877 - abp zagrzebski J. Mihalovič

10 T. Włodarczyk, Konkordaty. Zarys historii ze szczególnym uwzględnieniem XX wieku, Warszawa 1974, s. 136.

11 F. Engel-Janos i, Osterreich und der Vatikan 1844-1918, Bd. 1 (1846-1903), Graz 1958, s. 45 nn., 82 n.

12 Pii IX Pontificis Maximi acta, pars 1. vol. 2, Romae 1956, s. 492-494.

18 Hierarchia cath. vol. 8, Patavii 1978, s. 10, 12-14. 
i abp wiedeński J. R. Kutschher); kard. Franzelin był pierwszym z kardynałów austriackich pracujących w tym okresie w Kurii papieskiej ${ }^{14}$.

Tej liczby czterech kardynałów koronnych pilnował bardzo pilnie rząd austriacki, a w okresie pontyfikatu pap. Leona XIII (1878-1903) podjął starania o jej zwiększenie. Wspomniany papież w ciągu 25 lat swego pontyfikatu na łączną liczbę 147 kreowanych kardynałów wyniósł do tej godności 16 prałatów austriackich. Francja otrzymała ich 19, zaś Hiszpania - $11^{15}$. Z promocją kard. Albina Dunajewskiego, księcia biskupa krakowskiego (22 VI 1890), Galicja otrzymała prawie stałe przedstawicielstwo w Kolegium św. Po śmierci kard. Dunajewskiego ( $† 18$ VI 1894) władze wiedeńskie zaproponowały do purpury kardynalskiej arcybiskupa salzburskiego J. Hallera i metropolitę unickiego ze Lwowa Sylwestra Sembratowicza. Przy kandydaturze tego ostatniego władze wiedeńskie zrobiły uwagę, że ambasador austriacki przy Watykanie winien specjalnie podkreślić, że ,rzymsko-katolicki metropolita Lwowa, Seweryn Morawski, jest starszy w randze od metropolity unickiego Sembratowicza i przez promocję tego ostatniego może być bardzo urażony, ale okoliczność zbliżającej się rocznicy 300-lecia unii brzeskiej skłoniły rząd cesarski do zaproponowania kandydatury metropolity Sembratowicza". Toteż faktycznie na konsystorzu w dniu 29 listopada 1895 r. metropolita Sembratowicz i metropolita Haller z Salzburga otrzymali purpurę kardynalską ${ }^{16}$.

W dniu 4 sierpnia 1898 r. zmarł we Lwowie metropolita Sembratowicz, na skutek czego w Galicji nie było kardynała. Wniosek Ministerstwa Kultu i Oświaty z dnia 4 IV 1899 r., skierowany do ówczesnego ministra spraw zagranicznych Austro-Węgier hr. Agenora Gołuchowskiego ( $† 1921$ ) wysunął jako kandydata do purpury nie prałata z Galicji, ale metropolitę Gorycji Jakuba Missia; ten też otrzymał promocję kardynalską w dniu 19 VI 1899 r. ${ }^{17}$ Ale i Galicja miała czekać niezbyt długo na własnego purpurata. Dnia 25 kwietnia 1899 r. zmarł kard. Franciszek de Paula Schönborn, książę arcybiskup praski. Teraz tedy otworzyła się możliwość nadania purpury prałatowi z Galicji, a miał nim być książę biskup krakowski, Jan kniaź z Kozielska Puzyna.

Kim był nowy kandydat do purpury kardynalskiej? Urodzony w dniu 13 IX 1842 r. w Gwoźdcu Jan Maurycy Paweł Puzyna był synem Romana, majora wojsk austriackich, i Konstancji, córki generała Józefa Dwer-

14 Tamże, s. $19-23$.

15 Tamże, s. $28-42$.

${ }^{16}$ HHS . (Haus- Hof- und Staatsarchiv. Wien) 271 P. A. XI: Vatikan. Päpstliche Stuhl VI (Hh. Kolnoky do amb. Revertery - 28 XI 1894; hr. Revertera do hr. Kolnoky - 4 XII 1894; telegram hr. Revertery - 28 XI 1895).

17 Tamże (Min. kultu i ośw. do hr. Gołuchowskiego - 4 IV 1899; ambasador hr. Reveriera do hr. Gołuchowskiego - 24 IV 1899); Hierarchia cath., vol. 8 s. 40. 
nickiego. Mając lat 18 ukończył gimnazjum we Lwowie, a następnie studiował prawo na uniwersytecie w Pradze czeskiej i we Lwowie. We Lwowie też otrzymał promocję na doktora praw (24 VI 1870). Po 6 latach pracy $\mathrm{w}$ prokuraturze miasta Lwowa i mając 34 lata życia wstąpił Jan Puzyna w 1876 r. do Seminarium Duchownego w Przemyślu, gdzie już w dniu 8 grudnia 1878 r. otrzymał święcenia kapłańskie z rąk biskupa przemyskiego Macieja Hirschlera. Po rocznej pracy duszpasterskiej na stanowisku wikariusza w Przeworsku został zamianowany w r. 1879 wicerektorem Seminarium Duchownego w Przemyślu, a w r. 1880 został kanonikiem kapituły przemyskiej. W ósmy roku kapłaństwa wybrał $\mathrm{Pu}-$ zynę na biskupa pomocniczego metropolita ob. łac. we Lwowie Seweryn Morawski. Prekonizacja papieska nastąpiła w dniu 26 II 1886 r., konsekrację otrzymał $\mathrm{z}$ rąk kard. Mieczysława Ledóchowskiego w dniu 25 marca 1886 r. w Rzymie ${ }^{18}$.

Jako biskup pomocniczy we Lwowie ks. Puzyna został równocześnie rektorem Seminarium Duchownego. Na tych stanowiskach zreorganizował seminarium i studia seminaryjne, rozbudził na wielką skalę akcję misji parafialnych, a nade wszystko jeden $\mathrm{z}$ pierwszych dostrzegł niebezpieczeństwo ruszczenia się ludu polskiego we wschodniej Galicji poprzez udział w unickiej liturgicznej służbie Bożej, ze względu na rzadką sieć łacińskich placówek duszpasterskich. Zainicjował przeto w archidiecezji lwowskiej ob. łac. akcję budowy kościołów i kaplic mszalnych, na skutek czego liczba placówek duszpasterskich w archidiecezji wzrosła z 270 (1885) do 292 (1896), a liczba kaplic mszalnych do przeszło $400^{19}$. Po śmierci kard. Dunajewskiego za jego kandydaturą na Kraków wypowiedział się nade wszystko ówczesny namiestnik Galicji hr. Kazimierz Badeni. Zalecał go jako tego, ,co ma liczne zalety ducha i serca, z których dał się poznać zarówno na polu działalności państwowej i kościelnej, że jest sumiennym i na wysokim poziomie w wypełnianiu obowiązków swego powołania kapłańskiego. Dał się też poznać jako książę Kościoła, wykazując wiele inicjatywy i zdolności organizacyjnych". Jego też ces. Franciszek Józef I zamianował biskupem krakowskim (7 X 1894), a pap. Leon XIII prekonizował go na tę stolice biskupią (22 I 1895); 17 lutego tr. odbył uroczysty ingres do katedry św. Wacława i św. Stanisława Biskupa na Wawelu ${ }^{20}$.

Jako biskup krakowski w trosce o wzrost powołań kapłańskich za-

18 Hierarchia cath., vol. 8 s. 379; E. Komar, Kardynał Puzyna, Kraków 1912, s. $3-5$.

${ }_{19}$ E. Ko m a r, jw., s. 5; Catalogus [...] archidioec. Leopoliensis rit. lat. 1885, Leopoli 1885, s. 188 n.; Catalogus [...] archidioec. Leopoliensis rit. lat. 1897, Leopoli 1897 , s. 27 nn., $225-229$.

${ }_{20}$ B. Kumor, Obsada biskupstwa krakowskiego w latach 1790-1914, „Analecta Cracoviensia" 8 (1976) s. 337-338; E. K o m a r, jw., c. s. 229. 
łożył małe seminarium (1895), pomnożył wydatnie szeregi kapłanów w diecezji, wybudował nowy gmach seminarium duchownego, a jego prowadzenie polecił księżom diecezjalnym (1901) i rozpoczął wysyłać $z$ dolniejszych alumnów na studia uniwersyteckie (1895). Zajął się też wychowaniem przyszłych nauczycieli, przeprowadził gruntowną wizytację diecezji, zwrócił uwagę na rzetelną katechizację młodzieży i dzieci szkolnych, zwoływał systematyczne kongregacje dziekanów, na których omawiano sprawy emigracji i opieki duszpasterskiej nad emigrantami, katechizacji, zabezpieczenia zabytków sakralnych itp. Wydał też nowy porządek nabożeństw, ujednolicając służbę Bożą w całej diecezji (1898). Przeprowadził wielką restaurację katedry na Wawelu. Szereg reform poczynił w konsystorzu biskupim i w kapitule katedralnej. Często wypowiadał się na temat kwestii społecznej, popierał rozwój bractw i towarzystw kościelnych, zwłaszcza bractwo wstrzemięźliwości i Konferencji św. Wincentego a Paulo. Niewątpliwie był to jeden $\mathrm{z}$ bardziej energicznych duszpasterzy wśród ówczesnego episkopatu galicyjskiego ${ }^{21}$.

Dlaczego wybór kandydata do purpury kardynalskiej padł na osobę księcia biskupa Puzyny? Kraków był najbardziej tradycyjną stolicą kardynalską w Polsce. Liczba purpuratów w Krakowie była większa, niż w Gnieźnie prymasowskim. W okresie niewoli narodowej była to jedyna stolica biskupia na ziemiach polskich, której dwóch ordynariuszów było kardynałami, przy czym tradycję tę wznowił kard. Albin Dunajewski ( $\dagger$ 1894). Kreowany bowiem w 1856 r. kardynałem metropolita unicki we Lwowie Michał Lewicki był Rusinem, a kard. Mieczysław Ledóchowski od chwili otrzymania purpury przebywał poza diecezją (1875) ${ }^{22}$.

Pod uwagę można było wziąć łacińskich metropolitów we Lwowie, ale trzeba przyznać, że żaden $\mathrm{z}$ nich nie otrzymał purpury kardynalskiej. Ówczesny metropolita lwowski ob. łac. Seweryn Tytus Morawski miał już wówczas 80 lat życia, był schorowany i słaby, zresztą niebawem zmarł ( $\dagger 2$ V 1900) zanim Galicja otrzymała nowego kardynała. Kiedy zaś Lwów otrzymał następnego metropolitę łacińskiego w osobie Józefa Bilczewskiego (17 XII 1900), sprawa kardynalatu biskupa Puzyny była już w Rzymie załatwiona ${ }^{23}$. W grę mogła wprawdzie wejść kandydatura metropolity lwowskiego ob. gr.-kat. Juliana Kuiłowskiego (od

21 J. Urban, Nadzwyczajne formy duszpasterstwa $w$ diecezji krakowskiej $z a$ rzqudów ks. Kardynała Jana Puzyny (1895-1911) w swietle źódet drukowanych, Kraków 1978 (maszynopis), s. 16 nn.; E. K o m a r, jw., s. 17 nn.

22 S. Dobrzanowski, Restauracja diecezji krakowskiej w latach osiemdziesiatych XIX wieku, [w:] Studia $z$ historii Kościoła $w$ Polsce, t. 3. Warszawa 1977, s. $154 \mathrm{n}$.

23 B. Kumor, Morawski Seweryn Tytus, [w:] Polski Stownik Biograficzny, t. $21(1976)$ s. 742 n.; W. U r ba n, Stuga Boży Józef Bilczewski arcybiskup metropolita lwowski 1860-1923, Wrocław 1977, s. $26 \mathrm{nn}$. 
1 VI 1899), ale i on miał już 73 lata i był słabego zdrowia ( $\dagger 4 \mathrm{~V} 1900$ ). Zresztą zdrowa polityka władz austriackich wymagała, by tym razem po śmierci kard. Sembratowicza, Rusina, purpurę otrzymał Polak. Biskupów Przemyśla i Tarnowa, podobnie jak metropolity lwowskiego ob. orm., nie brano pod uwagę. Pozostał więc biskup krakowski Puzyna.

Wkrótce po śmierci kard. F. Schönborna z Pragi († 25 VI 1899), kiedy zwolniło się jedno miejsce dla kardynała koronnego, minister wyznań i oświaty Wilhelm August von Hartel po porozumieniu się z ces. Franciszkiem Józefem I zwrócił się w poufnym piśmie w dniu 18 XI 1899 r. do ministra spraw zagranicznych hr. Gołuchowskiego o przedstawienie kandydatury biskupa Puzyny do purpury kardynalskiej pap. Leonowi XIII. „Na księcia biskupa Puzynę według ministra Hartela ze względu na jego osobowość, jak też i wielkie wpływy, znaczenie historyczne biskupstwa krakowskiego [...] można wskazać jako na tego, który w pierwszej linii winien być wzięty pod uwagę przy stawianiu kandydatów do purpury kardynalskiej". Przy końcu listu minister Hartel prosił ministra Gołuchowskiego o wszczęcie odpowiednich kroków w tym celu w Rzymie. W trzy dni później (21 XI tr.) hr. Gołuchowski, przekazał tę sprawę ambasadorowi austro-węgierskiemu przy Watykanie hr. Reverterze ${ }^{24}$.

Rzym nie zawsze akceptował kandydatów austriackich do kardynalatu. I tak przez wiele lat, mimo ponawianych wielokrotnie petycji, Rzym opierał się kreowaniu kardynała prymasa Węgier Jana Simora. Prymasem został on 22 II 1867 r. i wkrótce potem rząd austro-węgierski zaczął zabiegać w Rzymie o purpurę kardynalską dla niego, ale otrzymał ją dopiero po 6 latach (22 XII 1873) ${ }^{25}$. Podobnie wystawiony 12 III 1914 r. do purpury kardynalskiej metropolita lwowski gr. kat. Andrzej Szeptycki nigdy jej nie otrzymał ${ }^{26}$.

Wobec kandydatury biskupa Puzyny Stolica Swięta nie zgłosiła żadnych zastrzeżeń i od razu ją zaakceptowała. Austriacki ambasador przy Watykanie hr. Revertera, po przeprowadzeniu rozmowy na ten temat z ówczesnym sekretarzem stanu kard. M. Rampollą, donosił 27 XI 1899 r. do hr. Gołuchowskiego: „Jego Eminencja oświadczył, że sprawę jak najszybciej przekaże Ojcu św., ale równocześnie podał mi do wiadomości, że na najbliższym konsystorzu nie są przewidziane promocje

${ }^{24}$ HHSt. Wien. 271 P. A. Vatikan. Päpstl. Stuhl VI (min. von Hartel do min. Goluchowskiego - 18 XI 1899; ,nach seiner persönlichen Stellung als nach seinem Einflusse und der historischen Bedeutung seines Bisthums der Fürstbischof von Krakau geheimer Rath Johann Puzyna Kniaź von Kozielsko wohl als derjenige bezeichnet werden, der in erster Linie für die Verleihung des Purpurs in Betracht zu ziehen wäre").

25 Hierarchia cath., vol. 8 s. 528.

26 HHSt. Wien. 272. P. A. XI: Vatikan. Liasse Päpstlicher Stuhl VI (min. wyznań rel. i oświaty do min. spr. zagr. - 12 III 1914). 
kardynalskie, stąd też przekazanie biskupowi Puzynie kardynalskiego kapelusza może się odbyć dopiero na późniejszym konsystorzu". Dodawał też, że prawdopodobnie taki konsystorz odbędzie się wczesną wiosną 1900 r. $^{27}$

Wspomniany przez kard. Rampole grudniowy konsystorz rzeczywiście miał miejsce 14 grudnia 1899 r., na którym pap. Leon XIII wyznaczył kardynałów legatów do otwarcia drzwi jubileuszowych w bazylikach rzymskich z okazji wielkiego jubileuszu, zapowiedzianego jeszcze w maju na rok 1900. Promocji kardynalskich na tym konsystorzu nie było ${ }^{29}$. Przewidywany na wiosnę $1900 \mathrm{r}$. konsystorz papieski odbył się 19 kwietnia, ale i na nim promocji kardynalskich nie było.

Tymczasem w dniu 5 maja 1900 r. zmarł kard. Jan Haller, metropolita salzburski, a liczba kardynałów koronnych w Cesarstwie spadła do dwóch; wszystkich kardynałów w granicach Cesarstwa było czterech, podczas gdy na przełomie XIX i XX wieku było ich zwykle sześciu. Byli to: książę arcybiskup wiedeński A. J. Gruscha († 1911), prymas Węgier kard. C. F. Vaszary († 1915), kard. W. Schlank - biskup Wielkiego Waradynu ( $\dagger$ 1902) i kard. J. Missia - metropolita Gorycji ( $\dagger$ 1902). W związku ze śmiercią kard. Hallera minister wyznań i oświaty von Bernd po porozumieniu się z ces. Franciszkiem Józefem I wysunął kandydaturę do purpury kardynalskiej młodego, bo liczącego zaledwie 37 lat, nowego metropolitę Pragi Leona Skrbenskyego, który co dopiero (14 XII 1899) został prekonizowany przez papieża na ten urząd. Sprawę tę minister Bernd przekazał do dalszego załatwiania ministrowi Gołuchowskiemu (7 IV 1900) ${ }^{29}$. Tak więc sprawa kreowania kardynałem biskupa Puzyny związała się odtąd mocno z kardynalatem metropolity praskiego Skrbenskyego.

Tymczasem sprawa kreowania kardynałem arcybiskupa Skrbenskyego natrafiała w Kurii papieskiej na nie oczekiwany opór. W dniu 18 kwietnia $1900 \mathrm{r}$. ambasador austriacki przy Watykanie po rozmowie z kard. Rampollą, w której przedstawił mu kandydaturę arcybiskupa Skrbenskyego, usłyszał odpowiedź, że wprawdzie konsystorz papieski odbędzie się $\mathrm{w}$ jesieni i na nim będzie kreowany kardynałem biskup Puzyna, ale arcybiskup Skrbensky ,,jako zbyt młody” będzie musiał zaczekać do dalszego konsystorza. Tak relacjonował sprawę hr. Gołuchowskiemu ambasador w liście z 21 IV 1900 r. ${ }^{30}$ To stanowisko Stolicy Apostolskiej w sprawie kardynalatu Skrbenskyego zaważyło na pewno na

${ }^{27}$ Tamże (hr. Revertera do hr. Gołuchowskiego -27 XI 1899).

23 Hierarchia cath., vol. 8 s. 17.

29 HHSt. Wien. 272. P. A. XI: Vatikan. Liasse Päpstlicher Stuhl VI (min. wyzn. rel. i oświaty do hr. Gołuchowskiego - 7 IV 1900); Hierarchia cath., vol. 8 s. 469 (Skrbensky), 493 (Haller).

${ }^{30}$ Tamże (hr. Revertera do hr. Goluchowskiego - 21 IV 1900). 
tym, że papież odwlekał ze zwołaniem konsystorza, jako że na tym tle rozpoczął się prawie roczny spór między Wiedniem a Watykanem. $\mathrm{Na}$ kardynalat musiał też czekać biskup Puzyna.

Odmowna odpowiedź Rzymu wywołała nerwową reakcję Wiednia. $\mathrm{Na}$ posiedzeniu w dniu 8 maja 1900 r. niektórych członków rządu w obecności ces. Franciszka Józefa I sprawę przedyskutowano jeszcze raz i w dniu 14 maja skierowano do ministra hr. Gołuchowskiego przynaglenie, by ten interweniował $\mathrm{w}$ Watykanie za pośrednictwem ambasady austriackiej. „Upoważniono przeto hr. Reverterę do przedłożenia jeszcze raz kardynałowi sekretarzowi stanu Rampolli wniosku, że Jego Majestat ces. Franciszek Józef I na skutek śmierci kard. Jana Hallera przedkłada kandydatów do purpury kardynalskiej w osobach biskupa Krakowa Jana Puzyny i księcia arcybiskupa Pragi Leona Skrbenskyego". Ponieważ w Wiedniu przypuszczano, że konsystorz papieski „nie jest obecnie przewidziany”, dlatego zobowiązywano ambasadora, by ,zabiegał o wcześniejsze jego zwołanie". Do listu ces. Franciszek Józef I dopisał własnoręcznie: „Przekazane pismo do Waszej Świątobliwości zaopatruję w mój własnoręczny podpis - $13 \mathrm{~V} 1900 "{ }^{31}$.

W Rzymie nadal jednak konsystorza nie zwoływano i wciąż się upierano przy tym, że „Skrbensky jest tak bardzo młody”. Stwierdził to sam pap. Leon XIII wobec ambasadora austriackiego w dniu 3 II 1901 r. Ambasador zaś dokazywał sztuki dyplomatycznej, by życzenie swoich mocodawców zrealizować. W dniu 19 XI 1900 r. złożył w tej sprawie protest i zagrozil, ,że nie weźmie udziału w publicznym konsystorzu, jeżeli arcybiskup Skrbensky nie otrzyma kapelusza kardynalskiego". Nie było natomiast problemu z kardynalatem biskupa Puzyny, ale sama sprawa się bardzo odwlekała. Protest i groźba ambasadora Revertery pomogły, jako że na skutek tego Watykan oświadczył, że arcybiskup Skrbensky otrzyma kapelusz kardynalski, ale dopiero w maju 1901 r. Tę wiadomość przetelegrafował do Wiednia ambasador $\mathrm{w}$ dniu 22 XI $1900 \mathrm{r}^{32}$

Wiadomość ta nie zadowoliła jednak Wiednia, gdzie życzono sobie, aby obydwaj kandydaci otrzymali kapelusze kardynalskie na najbliższym konsystorzu, którego spodziewano się na wiosnę 1901 r. Polecono więc hr. Reverterze podjęcie dalszych starań w Rzymie. Musiały być one nie najłatwiejsze, skoro dopiero 3 II $1901 \mathrm{r}$. otrzymał on audiencję u pap. Leona XIII, któremu przedstawił życzenia dworu cesarskiego. Ale i tym razem papież powtórzył zastrzeżenia co do osoby arcybiskupa Skrbenskyego, „że jest zbyt młody”, chociaż ostatecznie zgodził się obydwóch

31 HHSt. Wien, 7 K. Z. $1900 \mathrm{Nr}$ 1270/1900 (wniosek Dworu do min. spraw zagr. $-8 \mathrm{~V} 1900)$.

32 HHSt. Wien. 271 P. A. XIV: Vatikan. Päpstl. Stuhl VI (hr. Revertera do hr. Gołuchowskiego - 19 XI 1900; telegram hr. Revertery - 22 XI 1900). 
kandydatów cesarskich kreować kardynałami na najbliższym konsysto$\mathrm{rzu}^{33}$. Datę tajnego konsystorza ustalono na 15 kwietnia $1901 \mathrm{r}$. Tego też dnia pap. Leon XIII kreował i ogłosił publicznie 10 nowych kardynałów; było wśród nich 8 Włochów i 2 Słowian - biskup Puzyna z Krakowa i arcybiskup Skrbenșky z Pragi. Wśród Włochów kard. S. Martinelli był delegatem apostolskim w Stanach Zjednoczonych, trzech dalszych było urzędnikami w Kurii papieskiej, a czterech pracowało jako biskupi w duszpasterstwie ${ }^{34}$.

Nowo kreowany kardynał krakowski nie był obecny na tajnym konsystorzu w Rzymie w dniu 15 IV 1901 r. Jako kardynał koronny biret kardynalski miał otrzymać z rąk ces. Franciszka Józefa I. W dniu 16 IV tr. hr. Gołuchowski powiadomił go telegraficznie, że wręczenie biretów kardynalskich obydwom nowym purpuratom odbędzie się 25 kwietnia tr. w stolicy Węgier Budapeszcie w miejscowej Burgkirche. Tak się też faktycznie stało ${ }^{35}$. Po wręczeniu biretów purpuratom ces. Franciszek Józef I podziękował osobiście papieżowi za obydwie promocje (14 V 1901), a kardynał Puzyna powiadomił europejskie dwory panujące o swojej nominacji. Taka bowiem była tradycja, której miało stać się zadość, jako że kardynałowie cieszyli się przywilejami książąt krwi ${ }^{36}$.

W dniu 9 czerwca tr. pap. Leon XIIl na publicznym konsystorzu w kaplicy sykstyńskiej, po uprzednim złożeniu odpowiedniej przysięgi, dopuścił trzech nowo mianowanych kardynałów — biskupa Puzynę z Krakowa, arcybiskupa Skrbenskyego z Pragi i arcybiskupa Martinelli, delegata apostolskiego ze Stanów Zjednoczonych - do ucałowania pierścienia Rybaka i nałożył im kapelusze kardynalskie. Tegoż dnia na tajnym konsystorzu wręczył im pierścienie kardynalskie i wyznaczył im kościoły tytularne w Rzymie. Kardynał Puzyna otrzymał bazylike śś. Gerwazego i Protazego Męczenników ${ }^{37}$.

Tak otrzymał Kraków 8. z rzędu kardynała, który miał się cieszyć tą godnością przeszło 10 lat. Zmarł bowiem 8 IX 1911 r., a sekretarz kapituly krakowskiej widział w nim ,,prawdziwie męża Bożego, odnowiciela bazyliki, twórcę małego seminarium duchownego i reorganizatora Wyższego Seminarium Duchownego w Krakowie" ${ }^{38}$. Warto tu dodać,

3s Tamże (telegram hr. Revertery do hr. Goluchowskiego - 3 i 4 II 1901).

${ }^{34}$ Hierarchia cath., vol. 8 s. $41-42$.

35 HHSt. Wien. 36 F. Kardinäle $1 / 11-14,2 / 1-18.1870-1918$ (min. Gołuchowski - telegram 16 IV 1901); B. Ku mor, Obsada, s. 338.

${ }^{36}$ HHSt. Wien. 36 F., jw., (ces. Franciszek Józef I do pap. Leona XIII - $14 \mathrm{~V}$ 1901 ; kard. Puzyna do hr. Gołuchowskiego - 25 V 1901).

37 Tamże (hr. Szécsen do hr. Goluchowskiego, telegram - 9 VI 1901); HHSt. Wien. 271. P. A. XI: Vatikan. Liasse Päpstl. Stuhl VI (telegram - 9 VI 1901); Hierarchia cath., vol. 8 s. 41.

${ }_{38}$ Archiwum Kapituły Metropolitalnej w Krakowie. Acta actorum Illustris Capituli Ecclesiae Cathed. Cracov. ab anno 1906-1927 (bez paginacji pod datą 8 IX 1911). 
że wśród 147 promowanych przez pap. Leona XIII kardynałów było 77 Włochów $\left(55,78^{\circ} \%\right), 19$ Francuzów $\left(12,93^{\%} \%\right), 11$ Hiszpanów $(7,48 \%), 15$ $\mathrm{z}$ Cesarstwa Austriackego w tym 7 Austriaków (4,76\%), 3 Polaków $(2,04 \%)$, tyluż Węgrów i dwóch Czechów $(1,36), 6$ Niemców $(4,08 \%)$, po dwóch Portugalczyków, Anglików, Belgów, Irlandczyków $(1,36 \%)$, oraz po jednym z Australii, Kanady, Stanów Zjednoczonych, Szwajcarii, a nadto jeden Ukrainiec i jeden Ormianin. Można więc bez przesady powiedzieć, że kolegium kardynalskie w okresie pontyfikatu pap. Leona XIII stało się rzeczywiście międzynarodowe ${ }^{39}$.

\section{DAS KARDINALAT DES KRAKAUER BISCHOFS JAN PUZYNA}

\section{Zus a m m en f a s ung}

Das josephinische Regime in Österreich blieb unwillig gegen die kirchilichen Würden, die der Heilige Stuhl den österreichischen Bischöfen verlieh. Erst nach 1842 hatte der Prinz von Metternich diese Ansicht von Wien radikal geändert und einen Gedanken eingegeben, daß der österreichische Kaiser sein Vorrecht ausnützte, 6 Kronkardinäle präsentieren zu dürfen. Dies wurde von der Regierung, bei der Gelegenheit der Abschliessung des Konkordats, im Jahre 1855 in Rom positiv erledigt. Seitdem präsentierte der Kaiser dem Papst die Kronkardinäle, indem er durch die Staatskanzlei und die Österreichische Botschaft im Vatikan seine Kandidaten vertraulich vorschlug.

Unter dem Pontifikat Pius IX. (1846-1878) erhielt sich die Zahl von 4 Kronkardinäle, in Österreich aufrecht, aber schon vom Papst Leon XIII. (1878-1903) wurde sie bis zu 6 erhöht. In dem Augenblick, wo der Krakauer Bischof A. Dunajewski zum Kardinal ernannt wurde, erhielt Gralizien seinen Vertreter in dem Heiligen Kollegium.

Noch 1899 stellte Kaiser Franz Joseph I. die Kandidatur des Bischofs Puzyna zur Purpur auf, nachidem Kard. F. Schönborn, Erzbischof von Prag, gestorben war. Diese Kandidatur wurde von Rom noch vor 27.11.1899 akzeptiert. Da aber die Verleihung der Kardinalatswürde dem Bischof Puzyna mit der gleichen Angelegenheit des jungen Erzbischofs von Prag Leon Skrbensky verbunden war, dessen Kandidatur der Heilige Stuhl lange Zeit ablehnte, so mußte sich die Ernennung des Kardinalats für den Bischof Puzyna um 2 Jahre hinziehen, und sie erfolgte erst 15.4.1901.

39 Hierarchia cath., vol. 8 s. 28-42. 